\title{
What Drives Private and Public Merger Waves in Europe?
}

\author{
This version: August $25^{\text {th }}$ \\ Work in progress - please do not quote
}

Benjamin W. Blunck (bblunck@econ.au.dk)
School of Economics and Management
University of Aarhus

$\&$

Jan Bartholdy (jby@asb.dk)

Aarhus School of Business

University of Aarhus

\begin{abstract}
:
What drives merger waves? Harford 2005 argues that mergers are an efficient response to economic shocks to an industry, whereas Rhodes-Kropf, Robinson \& Viswanathan 2005 argues that merger waves are driven by overvaluation of the acquiring firm, and to a lesser extent, the target firm. Both papers are based on empirical analyses of listed US firms. This paper presents additional evidence of merger waves in the European Union (EU). The use of European data allows a more detailed analysis, since firm level data is available for both listed as well as private transactions. This analysis reveals significant differences between driving forces for listed firms and for private firms. Public or listed firm mergers and acquisitions are primarily driven by overvaluation or behavioural factors, whereas private transactions are driven by economic factors.
\end{abstract}




\section{Introduction}

What drives merger waves? Harford 2005 argues that mergers are an efficient response to economic shocks to an industry, whereas Rhodes-Kropf, Robinson \& Viswanathan 2005 argues that merger waves are driven by overvaluation of the acquiring firm, and to a lesser extent, the target firm. Both papers are based on empirical analyses of listed US firms. This paper presents additional evidence of merger waves in the European Union (EU). The use of European data allows a more detailed analysis, since firm level data is available for both listed as well as private transactions. This analysis reveals significant differences between driving forces for listed firms and for private firms. Public or listed firm mergers and acquisitions are primarily driven by overvaluation or behavioural factors, whereas private transactions are driven by economic factors.

The economic shock view claims that shocks to the economic fundamentals of individual industries create opportunities for a profitable restructuring of industry assets (McGowan 1971), leading to industry merger waves if sufficient capital is available (Harford 2005). The market driven view asserts that relative increases in merger activity are caused by increases in market valuations, which allow overvalued bidders to swap expensive equity for the relatively inexpensive equity of target firms if target shareholder control is poor (Shleifer \& Vishny 2003) or target managers have less information on potential synergy gains than bidders (Rhodes-Kropf \& Viswanathan 2004). Jensen 2004 proposes that there are agency costs of overvaluation. In short, during a period of upward industry trends and the accompanying rise in stock prices and industry growth, self-serving managers are authorized by the board to 
conduct acquisitions under the guise of maintaining growth levels. Evidence on publicly held firms offers support for each of the 3 theories ${ }^{1}$.

Private transactions offer a unique possibility for testing these theories. If the economic shock theory is the driving force behind all transactions, then there is no difference between merger waves involving public acquirers and private transactions, both sets of firms are affected by the same basic economic conditions or shocks. The evidence presented suggests that this is not the case since there is no significant overlap between merger waves for the two types of firms. However, this does not reject the economic shock theory since transactions by the two types of firms may be driven by different motives.

For private firms it is difficult to imagine behavioural theories as a major driving force.

Private firms have no explicit share values that they can trade, and finding undervalued firms that are willing to sell is a costly affair. Since most private firms have few owners and often owner-managers they are not likely to part with their own shares cheaply. The empirical analyses support these contentions: only variables representing economic shocks are significant in explaining private firm merger waves, whereas behavioural variables show limited significance. Thus private merger transactions represent (optimal) responses to economic shocks and behavioural theories do not play a major part.

\footnotetext{
${ }^{1}$ Evidence has offered the importance of the economic shock view (Mitchell \& Mulherin 1996; Mulherin \& Boone 2000; Andrade, Mitchell \& Stafford 2001; Harford 2005), the market driven view (Ang \& Cheng 2003; Dong, Hirschleifer, Richardson \& Teoh 2006; Rhodes-Kropf \& Viswanathan 2005) or the agency cost perspective (Moeller, Schlingemann \& Stulz 2005)
} 
Since private transactions represents responses to economic shocks and there is not overlap between the merger waves for public and private firms, the obvious hypothesis is that public transactions are driven by overvaluation of behavioural factors. The empirical analysis supports this contention, since few of the economic shock variables are significant, while the behavioural variables explain a significantly larger part of the public firm merger waves. It is much less clear what drives private acquirers buying public targets and vice versa, though it seems that the timing of public acquirers purchasing private targets is more likely to be driven by synergistic reasons.

The rest of the paper proceeds as follows: The second section summarizes existing theory and evidence on the cause of the merger wave of the 90s. The third section argues the role of corporate ownership in merger wave theory. The fourth section identifies industry merger waves for the ownership sub-samples and tests timing differences across them. The fifth section presents empirical hypotheses and the proxy variables. The sixth section offers univariate and multivariate evidence on the drivers of merger activity in the sub-samples. Interpretations of the results are offered. The seventh section concludes. 


\section{The merger wave of the $90 \mathrm{~s}$ and merger wave theory}

Figure 1 shows that the aggregate merger activity in the US and EU-15 ${ }^{2}$ reported by the Thomson Financial's SDC Platinum database. There is in both economies a clear merger wave in 1995 to 2001 (as noted by Sudarsanam 2003 among others), with a distinctive peak in $1999-2000^{3}$. We notice that the oft-cited co-movement between merger activity and stock market levels holds true for the EU-15. The correlation between EU-15 merger activity and the average market-to-book ratio is 0,82 .

$<$ Insert Figure 1 here $>$

\subsection{Explaining the US public firm merger wave of the 90s}

The correlation between stock market levels and aggregate merger activity has been noted in reference to all of the 5 great US merger waves (Weston 1953, Nelson 1959, Gort 1969, Golbe \& White 1988, Jovanovic \& Rousseau 2002 among others). Both the public firm merger waves of the $80 \mathrm{~s}$ and 90 s experienced an increase in the use of stock financing compared with non-wave periods (Andrade, Mitchell \& Stafford 2001). Shleifer \& Vishny 2003 argue that these observations indicate that knowledge stock bidders take advantage of a sustained market mispricing caused by an irrational stock market by exchanging their

\footnotetext{
${ }^{2}$ These countries represent the established countries in Western Europe bound together by a) a free market, b) a partly shared regulatory agency to mitigate anti-competitive mergers, and c) (for ca. $80 \%$ of their collective GDP) a shared economic monetary system. European economic unification has been building up in the 1990s and was affirmed with the implementation of the 'Eurozone' monetary area on the $22^{\text {nd }}$ December 1998, which brought together 12 countries under one currency and one central bank, while 3 members (United Kingdom, Sweden and Denmark) maintained independent monetary systems.

${ }^{3}$ Among the European countries, UK merger market is by far the most active, accounting for roughly $29 \%$ of acquirers and targets. Controlling for economy size, the UK market has even surpassed the US over the past 25 years. This is also the case with regards to industry takeover frequency (Powell \& Yawson 2005).
} 
expensive capital units for the capital units of relatively undervalued firms. Knowledgeable bidders are able to take advantage of this mispricing when target managers wish to 'sell out' or are paid for their consent. Rhodes-Kropf \& Viswanathan 2004 offer that target managers may instead be less knowledgeable of the general market mispricing, leading them to underestimate the extent of overvaluation (vis-à-vis the deal synergy) present in a stock offer, and hence, increasing their proclivity for stock offers over cash offers during times of overvaluation. Both simple overvaluation proxies and more complicated renditions show that a short-run deviation from the true stock value increases the chances of being a bidder especially a stock bidder - in the past two merger waves (Rhodes-Kropf, Robinson \& Viswanathan 2005, Dong, Hirschleifer, Richardson \& Teoh 2006 and Ang \& Cheng 2003). In addition, Dong et al 2006 also finds that characteristics of bids by highly valued bidders match the predictions of the market driven view quite well. Furthermore, Dong et al argue that the evidence of the market driven view is most persuasive in the 90 s merger wave.

Jensen 2004 argues that the overvaluation of the 90s further increased the agency costs related to the separation of ownership and control. Specifically, the stock market overvalued the 'newness' of the 90s, leading to a period of over-inflated stock prices, in which firms were unable to fulfil the growth required through value-creating investments. Apparently to meet the stock market expectations, the boards allowed managers to pursue value destroying investments such as acquisitions. Though the agency costs of overvaluation have not been directly empirically linked to aggregate or industry merger activity, Jensen 2004 and Moeller, Schlingemann \& Stulz 2005 argue that the large shareholder losses incurred in 1998-2001 by acquisitive firms were caused by these forces and the subsequent re-evaluations of firm policies. Numerous papers add that the long-term decline in the market value of stock 
acquirers in merger waves supports behavioural conjectures, though this piece of evidence does not facilitate a distinction between competing behavioural theories.

Several authors have shown that the merger activity of the 80 s and 90 s varies significantly across industries (Mitchell \& Mulherin 1996, Andrade et al 2001 among others). Arguably, the industry clustering is mostly apparent in the 90s. McGowan 1971 and Mitchell \& Mulherin 1996 argue that industry-level motives are necessary to explain industry clustering, since general financial conditions do not vary enough across industries. Changes in the economic fundamentals of industry value creation lead to profitable industry restructuring opportunities, to which M\&A is an end (Mitchell \& Mulherin 1996, Weston 2001, Harford 2005). These changes may constitute various kinds and combinations of the PEST (Political, Economic, Social and Technical) factors (Sudarsanam 2003), and the motives may be synergistic and/or disciplinary in nature. Mergers are an 'adaptive phenomenon' (McGowan 1971), and often the cheapest method of restructuring in response to these industry economic changes (Mitchell \& Mulherin 1996) - and more so the larger the shock - in part due to the ability to avoid excess capacity (McGowan 1971, Mitchell \& Mulherin 1996, Lambrecht 2004). Numerous papers note the link between various individual shocks and industry merger activity (see Bruner 2003 for an anecdotal overview). This economic shock view ${ }^{4}$ attributes the observed stock market overvaluation to increased growth opportunities caused by the potential for industry reorganization and the decrease in the cost of capital. Harford 2005 finds that the timing of US industry merger waves in the $80 \mathrm{~s}$ and $90 \mathrm{~s}$ is related to the size of the combined economic industry shocks and ease of financing within the US economy, leaving no explanatory power to measures related to stock market levels. However, Rhodes-

\footnotetext{
${ }^{4}$ A related strand of literature - often referred to as the Q-hypothesis of takeovers (see for instance, Jovanovic \& Rousseau 2002) - argues a similar, but broader efficiency perspective. We treat them as synonymous.
} 
Kropf, Robinson \& Viswanathan 2005 show that a more direct measure of industry timeseries overvaluation univariately explains the timing of US industry merger waves. Stock and accounting evidence on the short and long run performance of mergers in merger wave provides conflicting evidence on the existence of synergy and acquirer gains, which is arguably due to the effect of exogenous and endogenous industry changes on the relevant (unobservable) benchmark (Sudarsanam 2003).

\section{Merger wave theory and corporate ownership}

According to the SDC database, the proportion of public firm mergers held constant around $24-28 \%$ during the years of the $5^{\text {th }}$ US merger wave. It is clear that these mergers covered the bulk of the wave's transaction value. On the other hand, only $7-11 \%$ of the wave's EU-15 mergers were public firm mergers. The bulk of these are due to the UK, which also provides approx. $35 \%$ of EU-15 listings. If anything, this difference between the US and the EU explains why we need to explain private firm merger waves. Outside of the US and the UK, we really have no evidence on what drives observed merger activity.

\subsection{Merger waves of publicly held firms}

In essence, existing merger wave theories of public firm merger clustering are based on synergy or deviations from rationality by decision-makers and financial markets. The market driven view argues that synergistic gains owing to continuous firm and industry adjustments may lead to a reasonably constant degree of merger activity, but that the peaks in merger activity are caused by an increase in stock swap mergers. Notably, this requires a wellinformed acquirer manager and a less-informed or self-interested target management team. The agency theory of overvaluation argues likewise that the stock market may sustain 
irrationally high stock prices before reverting to true values. However, this theory requires self-interested managers who are insufficiently controlled by their boards (perhaps themselves self-centred or irrational) and the shareholders. On the other hand, the economic shock view focuses on the synergy gains available to firms which can instil a shareholder rational manager and which cannot dupe the efficient capital markets. We could argue that the present state of the evidence on public merger waves points to the possibility that both synergistic and behavioural views coincide around periods of economic shocks, particularly in the 90s. Barring the influence of corporate governance differences between the EU-15 and the US, we expect this to carry over to the public firm European merger wave of the $90 \mathrm{~s}$.

\subsection{Merger waves of privately held firms}

However, whereas the economic shock view translates seamlessly to private firms, the behavioural view does not. Accepting the potential for these market inefficiencies, we argue that three influential factors are critically different in private firms - the informational environment, ownership structures and the behaviour of target shareholders.

In the case of the market driven view, the Rhodes-Kropf \& Viswanathan 2004 model is technically independent of the organization of firm ownership due to its assumptions of bidder and target firm knowledge. However, the premise for its sweeping assumptions is the informational climate of a well-developed stock market. However, private firms don't have stock prices, and while multiples are often used to calculate bid premia, the agreed price is not likely to reflect the mostly overvalued public deals - but most probably the average public merger price instead. In other words, the chance of realizing the same sort of advantage over a same-industry private target should be somewhat lower. Furthermore, even if there were 
potential gains to overvaluation, it is not clear that a potential bidder would find it ex-ante profitable to go in search of a suitable target firm, since the search costs and information asymmetries are greater for private firms. Given the lack of an informational environment, it is likely that the deal intermediaries (such as investment banks) play a more important role in the matching of firms. However, while it is entirely likely that their role may be valuedestroying in general, as described in connection with the agency cost perspective below, it seems less likely that they could present and sustain opportunities to take advantage of stock mispricing. In Shleifer \& Vishny 2003, the focus is shifted towards target managers' incentives to accept a bloated bid, since the acquirer and target manager are assumed to be fully knowledgeable. Like public target managers, private target managers may also accept an overvalued stock offer if it provides a private gain through a favourable realization of his/her own target stock holdings, a substantial payout, or alternatively, an improved job position within the continuing firm. While these private gains could well match that of a public bidder offer, we argue that the active ownership implied by the large private shareholders allows the target manager much less discretionary control over a private firm. It is also more likely that private firms have an owner-manager.

In addition, private bidders have a similar distaste for stock payment, since it can contribute to a significant control loss for large shareholders. This has been confirmed empirically by Faccio \& Masulis 2005.

The above argumentation on private target incentives is trivially applied to publicly held firms purchasing privately held targets. From the viewpoint of the public bidder, a private target requires a more extensive search than public targets, and therefore, it is ceteris paribus less 
probable that a public firm manager would attempt and succeed in taking advantage of public targets. Floegel, Gebken \& Johanning 2005 provides US evidence that private bidders are purchased relatively later in industry merger waves.

In relation to Jensen's agency costs of overvaluation, ownership structure is the key issue. Numerous studies imply that agency costs in general are higher in large, publicly held firms due to the increased monitoring of larger shareholders in smaller, private firms. It is also likely that large shareholders have a much longer investment horizon than that of public firm shareholders, leading them to discourage quick growth 'fixes' such as acquisitions. The lack of a 'naïve' stock market which demands the accomplishment of short and medium term growth estimates (Jensen 2004) is also a significant factor. Altogether this means that private shareholders are less likely to crave short term growth, and that the large-shareholderdominated board is less likely to condone it. On the other hand, we could argue that the significant role of deal intermediaries in company strategy - especially in times of business prosperity - may in fact lead to the maintaining of some overvaluation effects on private firms. Specifically, the intermediaries' role strengthens the institutional effects within the individual industry and the economy (Auster \& Sirower 2002). Intermediaries and media coverage etc. legitimize growth through acquisitions, which leads private firm boards and shareholders to view these strategies more favourably. Hence, it is likely that the agency costs of overvaluation affect private firms to some degree, although we would still expect these costs to be somewhat lower compared with public firms.

In summary, our baseline expectation is that the synergistic rationales, caused by economic shocks, explain industry merger waves of private acquirers buying private targets, whereas it 
is likely that publicly held firms buying other publicly held firms are influenced by the behavioural factors. Notably, we might conclude that there is all else equal a greater chance that merger waves of private acquirers buying publicly held targets are behaviourally driven than waves involving purely privately held firms. Under the market driven perspective, the increased informational environment surrounding the public target will increase the ability of a private acquirer to take advantage of perceived mispricing. Under the agency costs perspective, this improved informational environment lowers search costs, which all else equal makes it cheaper for a private firm manager to follow his own self-interested goals. In regard to waves of publicly held firms acquiring privately held firms, the informational costs would lead to a prediction that the chance for a behavioural motivation is lower than for purely publicly held merger waves. Following the market driven view, we could argue that 'public-private' merger waves have a lower chance of a behavioural influence than 'privatepublic' waves in that private targets much better controlled by target shareholders, and search costs of private targets are higher.

\section{The timing of industry merger waves}

We mentioned above that recent evidence shows that aggregate merger waves have a strong industry merger wave. Therefore, we analyse the cause of industry merger waves. In the sense that the variables related to behavioural issues move at an aggregate level, it will become prevalent in our industry level data.

\subsection{The European merger wave sample}

Our sample covers completed, control shifting transactions from January $1^{\text {st }}, 1995$ to December $31^{\text {st }}$, 2004 involving a country from the EU-15 (obtained from the SDC Platinum 
database) - a sample of 23.157 mergers. We drop observations relating to newly created joint ventures, mutual fund activity and government mergers. Unlike previous studies, we maintain both public and private mergers regardless of transaction size $\mathrm{e}^{5}$.

We define 47 industry groups (from hereon: industries) on the basis of SIC codes, using the Fama \& French 1997 definitions $^{6}$. To allocate merger activity to these industries, we use a procedure which takes into consideration the use of pyramidal ownership structures in the EU. Specifically, we need to take into account those instances in which a higher level legal entity engages in activity on the part of a lower-level firm. Therefore, we construct a three-level procedure. Firstly, if the primary industries of the acquirer and target firm match up, we allocate this as a merger within the shared industries. If this is not the case, we compare the secondary industries of the acquirer with the primary industries of the target, allocating the merger to the shared industries if there is a match. Lastly, we compare the secondary industries of the firms, allocating the merger to the industries in which we find the most overlaps, if any. If there is no match on either level, we define the merger as unrelated and allocate it to both the industry of the acquirer and the target.

\subsection{Identifying merger waves}

Following Harford 2005, we define a potential industry merger wave as the highest 24-month concentration of merger activity within our 10 year sample. We then use the simulation

\footnotetext{
${ }^{5}$ Excluding deals without a reported value would remove approx. $56 \%$ of our sample. If we were to exclude deals below a value of $\$ 50$ million (as in Harford 2005), only $17 \%$ of our sample would remain. The removable of deals without a reported value and a transaction size below $\$ 50$ million would impact the number of private mergers much harder than mergers involving public firms (roughly $78 \%$ of transactions above $\$ 50$ million involve a public acquirer or target), which is probably due to the smaller size of private firms and their lower informational requirements.

${ }^{6}$ There are initially 48 industry groups relating to non-governmental corporations - we remove the 'Miscellaneous' industry, as it serves as a residual industry.
} 
method in Harford 2005 to ascertain whether these merger waves are statistically significant. Specifically, we simulate 1000 distributions of the actual number of mergers within each industry in the 10 year period, and determine the highest 24-month concentration of activity in each simulation. This leaves us with 1000 simulated industry merger waves for each industry. For each potential industry merger wave, we then compare the $95^{\text {th }}$ percentile of the 1000 simulated 24-month concentrations of industry merger activity with the actual 24-month concentration. We carry out this procedure on the full sample, the sample of public firm mergers and the private firm sample.

\subsection{Differences between private and public ownership}

Tables 1a-c show the placement and significance of the potential waves for each industry. Significant industry merger waves are depicted for whole, private and public samples (table 1a), followed by depictions of the potential and significant merger waves of the private and public firm sample respectively (tables $1 \mathrm{~b}-\mathrm{c}$ ). There are 35 significant waves in the whole sample, and 25 and 26 in the private and public samples respectively.

$$
<\text { Insert tables 1a-c here }>
$$

If we observe the potential industry merger waves in these sub-samples, we see that there are obvious differences in many industries, and only a handful of paired waves are within 6 months of each other. On average, the potential industry merger waves are 19,6 months apart. The Spearman rank order correlation measure is not statistically significant from zero at 0,15 . 
Interestingly, the private and public waves are only simultaneously significant on 14 occasions - and these waves are on average 21,4 months apart.

In all, we find differences between samples that cannot be dismissed as lagged, aggregate effects. In the following sections, we will test whether these differences can be attributed to the varying influence of synergistic and behavioural factors.

\section{Empirical predictions}

\subsection{Hypotheses}

The propositions in the literature introduced in section 3 can be summarized as follows: The economic shock view advocates that industry merger waves will be more likely when economic industry shocks are larger (Mitchell \& Mulherin 1996), and when capital liquidity is loose compared to tight (Harford 2005). However, periods of low capital liquidity will incapacitate the industry's ability to adjust to industry shocks through mergers (Harford $2005)$, thereby making the occurrence of an industry merge wave independent of the combined economic shock.

The market driven view postulates that stock market levels, as well as the intra-industry dispersion of these are correlated with the timing of industry waves (Shleifer \& Vishny 2003, Rhodes-Kropf \& Viswanathan 2004). On the other hand, the agency costs perspective does not require intra-industry dispersion of stock valuations, merely a period of prolonged overvaluation (Jensen 2004). 


\subsection{Predictive variables}

\subsubsection{Economic shocks}

Our economic shock data is retrieved from the Bureau van Dijk AMADEUS database, which contains accounting data on all active and inactive private and publicly held firms dating at least back to 1990. However, AMADEUS does not offer accounting data on banks and financial services firms, so we drop the Bank industry from our analyses. Each firm-year accounting observation is assigned to one of the remaining 46 industry groups based on their primary SIC code, giving us approx. 1,4 million industry memberships ${ }^{7}$.

In defining our measures of economic industry shocks, we take into consideration the proliferation of the pyramidal corporation structure. Instead of relying on the accounting data in the consolidated accounts, we use the unconsolidated accounts of the firm ${ }^{8}$. These firms are mainly single business entities, and their accounting numbers provide precise data on the fundamental economics of the industry.

We construct 6 accounting measures variables - cash flow margin, return on assets, sales growth, employee growth, asset turnover and capital expenditures ${ }^{9}$. Calculating the absolute change in each of these variables from period $t-1$ to $t$, we define our economic shock variables as the medians of these changes within each industry population of firms. In the accounting variables which follow, we therefore also restrict our focus to the operations. Unlike Harford

\footnotetext{
${ }^{7}$ Some firms change their industry membership within the period - this means that they will be counted once per industry membership.

${ }^{8}$ We limit our accounting sample to firms with more than 50 employees in at least one year within the period 1992-2005

${ }^{9}$ Harford 2005 includes data on research and development expenses, which is rarely reported by private firms and hence, not reported by AMADEUS. We therefore exempt this shock variable.
} 
2005 , the profitability measures use the profits from operations to avoid the influence of other lower or higher level companies in the firm pyramid. Following Harford 2005, we define a combined economic industry shock variable that encompasses the variation of the above 6 shock variables. Specifically, we calculate the first principal component of the covariance matrix, and create a linear combination of the shock variables using the weights of the principle component. This measure captures roughly $80 \%$ of the variation in the variables.

\subsubsection{The ease of financing}

We implement the capital liquidity factor pioneered by Harford 2005 - the spread between the average interest rate on commercial and industrial loans and the central bank rate - which supposedly captures the 'ease of financing' within an economy. When the measure is high, it means that capital liquidity is low, i.e. financing is expensive.

The measure is not trivially operationalized for the EU-15 countries. In fact, a commercial bank lending rate similar in purpose to the average lending rate on commercial and industrial loans published by the Federal Reserve was only initiated in January 2003 upon the successful implementation of the harmonization of interest rate statistics ${ }^{10}$. For 2003-2005, we construct a GDP-weighted average bank lending rate given the rates for the Eurozone and the 3 nonEuro countries. Pre-2003, we substitute the Eurozone rate for a synthetic version constructed by Datastream.

With regards to the central bank rate, we use a GDP-weighted average of the ECB marginal lending rate and the rates offered by the UK, Danish and Swedish national banks (available

\footnotetext{
${ }^{10}$ These rates are collected from appointed monetary financial institutions (MFIs) to be used in future ECB monetary policy analyses (Christoffersen \& Jakobsen 2003 among others).
} 
from www.eurostat.com). For the years prior to the inception of the Euro - i.e. post-1999we simply construct a weighted average of all national banks' marginal lending rates, readjusting the weighting in the few places where Eurostat displays missing values.

The changes in interest rate definitions will invariably create some noise in the capital liquidity proxy. Figure 2 below shows the relationship between aggregate EU-15 merger activity, the EU-15 market-to-book ratio and the rate spread. The rate spread has been mirrored at the vertical axis and all values have been raised by the value of the highest observation $(2,39 \%$ in 1996$)$. While it is clearly more volatile than the market to book ratio, there seems to be a co-movement with EU-15 merger activity (the correlation is only $-12,3 \%$, but the correlation of the absolute changes is $-52,8 \%$ ).

$<$ Insert Figure 2 here $>$

\subsubsection{Valuation factors}

We retrieved stock data for all active and inactive publicly held firms 1989-2005 from Datastream and allocate each firm year to the industry of its primary SIC code. Having removed those firm industry memberships which provide less than 3 consecutive years of data, we are left with 4.859 firm industry memberships. Our stock market variables are the industry median 1 and 3 year stock returns, the median market-to-book ratio at the year end, and the intra-industry standard deviations of these 3 series for each industry group. However, in light of the results of Rhodes-Kropf \& Viswanathan 2005, we also include their industry 
time-series error variable (specifically, the second of their 3 valuation models) as an industry overvaluation variable. We use the fitted values technique described in their paper to calculate the cross-sectional and time-series valuation error for each firm year. The valuation errors are calculated on the basis of 12 sectors (as defined by Fama \& French ${ }^{11}$ ). Having achieved crosssectional and valuation errors for all firm years, we define the industry times series error as the average firm times series error in a given industry (using our classification of 46 industry groups).

Some industries have very few public firms. We exclude industries having less than 5 firms providing stock return data in a sample year, which means that we drop 'Coal', 'Ships', 'Defs', and 'Gold' industry groups.

\section{Empirical results}

This section provides univariate and multivariate evidence on which ex-ante synergistic and behavioural factors can explain the timing of private and public industry merger waves.

\subsection{Univariate evidence}

For all predictive variables, we rank each industry year into quartiles, and then calculate the mean quartile rank of the years preceding industry merger waves. Table 2 provides the mean rank value of the predictive variables preceding an industry merger wave observation for private, private-public, public-private and public sub-samples, as well as for the whole sample.

\footnotetext{
${ }^{11}$ The sectors are 'Consumer nondurables', 'Consumer durables', 'Manufacturing', 'Energy', 'Chemicals', 'Computers, software etc.', 'Telephone and TV', 'Utilities', 'Wholesale', 'Medical', 'Finance', 'Everything else' (definitions are available on http://mba.tuck.dartmouth.edu/pages/faculty/ken.french/data_library.html)
} 
$<$ Insert Table 2 here $>$

The private merger waves are preceded by statistically significant high values of the individual economic shock variables, as well as the economic shock index itself. Notably, all economic shocks - related to profitability, sales and investment intensity - are above 3 . The corresponding rank values concerning the public waves are considerably lower and much less significant. While the efficiency and profitability measures are significantly above 2,5 , sales growth and employee growth are insignificant. Employee growth is even below 2,5. While the combined economic shock is significantly high for the private firm sample $(3,17)$, it is insignificant for the public firm sample at 2,78. Hence, both the individual and combined shocks have a lower influence on public firm merger waves.

Regarding the classic market driven factor - the market-to-book-ratio - it is above 2,5 in both sub-samples. However, while it is only marginally higher in the private firm sample, it is very high (and significant) in the public firm sample, in which it is 3,22. Turning to the stock returns, we see that both 1 year and 3 year stock returns are significantly higher preceding public firm merger waves - especially the 1 year returns (at 3,09). Interestingly, the 1 year stock returns are below 2,5 for private merger waves, and the 3 year returns are insignificant. While the standard deviations of the 1 and 3 year stock returns are less significant for the public firm sample, they are surprisingly high in the private merger sample, especially the 
deviation of the 3 year returns. Despite the significance of the other overvaluation measures, the time series error is insignificant in both samples, albeit being above 2,5.

The marked differences in the sign and significance of the market-driven variables between two sub-samples are also evident in the mean rank of the capital liquidity factor. Whereas it is below 2,5 for the private firm sample (as expected) - but insignificant - it is very high for the public firm sample $(3,26)$. The latter goes counter to the economic shock theory, which argues that capital liquidity is a necessary condition to facilitate the reorganization of industry assets through M\&A. However, in the case that public firms are driven by overvaluation theories, it is clear that the capital liquidity variable is of less importance. Therefore, this further cements our public firm evidence in favour of the behavioural theories, especially the market driven view.

On the public firm merger wave of the 80 s and 90s, Harford 2005 conducts that same tests on the mean rank values and finds results similar to our European public firm sample. However, we find a much higher significance for the 1 and 3 year stock returns, whereas he finds stronger evidence for the economic shock factors.

The two 'mixed' sub-samples show both marked differences and similarities with the two 'pure' samples. Firstly, the public-private sample shows even higher values of the economic shock variables than the wholly private sample (though capital liquidity is even less significant than in the latter). However, unlike the private sample, the market to book and the 1 and 3 year stock returns become much higher and significant. Even the time series error is now significantly above 2,5 . Like the private sample (but unlike the public sample), the 
dispersion in 3 year stock returns is now significant. We can conclude that the public-private sub-sample displays traits of all the theories at once, at least in a univariate sense.

Secondly, the private-public sample displays a great variation in the univariate importance of the individual shocks. Notably, capital expenditures has its highest mean rank in this sample. As in the private sample, the market to book variable is insignificant, and in this case, even below 2,5, which is odd compared with any of the theories. Despite the insignificance of most of the stock market variables, both the 3 years returns and the dispersion in these are above 3 and significant. In all, this sample has no clear adherence to our theoretical expectations. Notably, the capital liquidity factor is around 2 and significant, making it the only sample to display this feature of the economic shock view.

The mean rank values for the whole sample is similar to the public-private sample, which is hardly unexpected, as it mirrors the 4 sub-samples.

\subsection{Multivariate evidence}

We now turn to a logistic regression model to see whether the differences between the private and public samples, and the explanations offered by the initial univariate results, carry over to a multivariate setting.

\subsubsection{Logistic regression modelling}

Logistic regression modelling is used when the dependent variable is a binary response variable (i.e. when y is 0 or 1) (Woolridge 2002). In our case, the dependent variable is 1 if a merger wave begins in a given industry year, and 0 if no industry merger wave begins. Table 
3 reports the results for the full sample and the 4 sub-samples. This regression mirrors that of Harford 2005, but our analysis deviates in conceptual and practical ways. Firstly, we use the value of the capital liquidity proxy a given year, as opposed to the lagged value. It seems more correct to compare activity with a proxy measured at the time of the decision as opposed to historic values. Secondly, we use more behavioural variables than Harford 2005, which uses the 3 year returns, the dispersion in these, and the market to book value. We maintain both the 1 and 3 year stock returns, the dispersion in these, as well the mean and dispersion of market to book values. This allows us to capture the potentially varying importance of these behavioural variables across sub-samples. We leave out the industry time series error in our reported multivariate regression, as it fares much worse than the other valuation variables in initial univariate regressions (not reported). Thirdly, with regards to the use of logistic modelling, the maximum likelihood estimates cannot be interpreted as the marginal effects of the explanatory variables. Therefore, we calculate and report the true marginal effects on the probability of an industry merger wave using the methods detailed in Woolridge 2002. We take care to account for the complications arising as a result of our use of interaction effects. And since marginal effects in a logistic equation are a function of the specific values of the explanatory variables, we evaluate the marginal effects at their mean values.

$<$ Insert table 3 here $>$

Observing first the private sample, we see that the economic shock index is the only significant variable at just over 5\%. It is positive as expected. The variable denoting the effect of the shock index during periods of tight capital is positive and close to significance, 
implying that these periods do not remove the shock effect, and in fact, may even increase the effect of shocks. None of the behavioural variables are close to significance, and we can conclude that the private sample is caused by economic shocks.

The public sample on the other hand - which has seemed more governed by the behavioural views and less by the economic shock view - does indeed display some multivariate evidence in this regard. The economic shock index has no importance, while the 1 year stock returns are significantly positive. Strangely enough, the dispersion in these returns is significantly negative, which goes counter to the market driven story. However, the dispersion in market to book values is borderline significant and positive, which counters this unexpected result.

The mixed samples give unclear answers. The public-private sample has no significant variables, though the economic shock index is borderline significant at $12,9 \%$, implying that the economic shock view may be the most important of the two, despite the simultaneous univariate evidence for both theories. The multivariate evidence for the private-public sample is as unclear as the univariate evidence. Here, the economic shock index and capital liquidity are positive as expected by the economic shock view, while the 3 year returns are significantly positive, implying a behavioural influence as well. However, both the 1 year returns and the market to book have a significantly negative effect, so it seems difficult to conclude anything on this basis.

In all, both the univariate and multivariate results confirm our theoretical predictions and the initial statistics on merger wave timing in section 4. It is clear that the difference in timing (and significance) of private firm and public firm merger waves is caused by a deeply rooted 
difference in the driving forces. While the immediate correlation between aggregate merger wave activity and the market to book ratio seemed to indicate that the entire merger wave was timed according to stock market levels, our industry level analysis has exposed these differences between the timing and cause of private firm and public firm industry merger waves. We have also shown that the two samples mixing private and public acquirers and targets are different from both the extremes - perhaps governed by both theories at the same time - though we could offer that the public-private sample is mostly driven by economic shocks.

\section{Conclusion}

By analyzing the timing of private firm and public firm industry merger waves we have uncovered significant differences between the two types of merger waves. In fact, they make up two distinct components of the European merger wave of the 90 s. Specifically, we conclude that economic shocks explain the clustering of private firm merger waves. This implies that these merger waves are fundamentally driven by the existence of synergistic gains caused by shifts in industry economics. Conversely, we conclude that public firm mergers are most heavily influenced by measures of stock market overvaluation, signifying that these mergers are caused by the market timing of acquisitions by public acquirers. Furthermore, samples mixing private and public acquirers and targets seem to be influence by both economic shock and behavioural effects. We are as of yet unable to decipher whether the influence of stock market overvaluation on public firms is a result of Jensen's agency costs of overvaluation, or the market driven view of Rhodes-Kropf et al 2005 among others. Further research must attack this issue. 


\section{References}

Ang, J. S., Cheng, Y., Direct Evidence on the Market-Driven Acquisitions Theory, working paper, Florida State University, 2003

Andrade, G., Mitchell, M., Stafford, E., New Evidence and Perspectives on Mergers, The Journal of Economic Perspectives, Vol. 15, No. 2, p. 103-120, 2001

Andrade, G., Stafford, E., Investigating the Economic Role of Mergers, Journal of Corporate Finance, Vol. 10, p. 1-36, 2004

Auster, E. R., Sirower, M. L., The Dynamics of Merger and Acquisition Waves, Journal of Applied Behavioral Science, Vol. 38, No. 2, p. 216-244, 2002

Christoffersen, T., Jakobsen, M., New Interest-Rate Statistics, Monetary Review $2^{\text {nd }}$ Quarter, Danmarks Nationalbank, 2003

Dong, M., Hirschleifer, D. Richardson, S. Hong Teoh, S., Does Investor

Misvaluation Drive the Takeover Market?, Journal of Finance, Vol. 61, No. 2, 2006

Faccio, M., Masulis, R. W., The Choice of Payment Method in European Mergers and Acquisitions, Journal of Finance, Vol. 60, No. 3, 2005

Fama, E., French, K., Industry costs of equity, Journal of Financial Economics, Vol. 43, p. 153-193, 1997

Floegel, V., Gebken, T., Johanning, L., The Dynamics within Merger Waves - Evidence from Industry Merger Waves of the 1990s, unpublished working paper, European Business School, 2005

Golbe, D. L., White, L. J., A Time Series Analysis of Mergers and Acquisitions in the U.S Economy, in: Auerbach, A. J., (ed.), Corporate Takeovers: Causes and Consequences, Chicago, Illinois: University of Chicago Press, p. 265-302, USA, 1988

Gort, M., An Economic Disturbance Theory of Mergers, Quarterly Journal of Economics, Vol. 11, p. 241-273, 1969

Harford, J., What Drives Merger Waves?, Journal of Financial Economics, Vol. 77, No. 3, p. 483-702, 2005

Jensen, M. C., The Modern Industrial Revolution, Exit, and the Failure of Internal Control Systems, Journal of Finance, Vol. 48, No. 3, p. 831-880, 1993

Jovanovic, B., Rousseau, P. L., The Q-Theory of Mergers, American Economic Review, Vol. 92, No.2, 2002

Lambrecht, B. M., The Timing and Terms of Mergers Motivated by Economies of Scale, Journal of Financial Economics, Vol. 72, No. 1, p. 41-62, 2004

Massman, M., Mitchell, J., Reconsidering the Evidence: Are Euro Area Business Cycles Converging?, Journal of Business Cycle Measurement and Analysis, Vol. 1, No. 3, p. 275307, 2004

McGowan, J. J., International Comparisons of Merger Activity, Journal of Law and Economics, Vol. 14, p. 233-250, 1971

Mulherin, J. H., Boone, A., Comparing Acquisitions and Divestitures, Journal of Corporate Finance, Vol. 6, p. 117-139, 2000

Mitchell, M. L., Mulherin, J. H., The Impact of Industry Shocks on Takeover and Restructuring Activity, Journal of Financial Economics, Vol. 41, p.193-229, 1996

Moeller, S., Schlingemann, F., Stulz, R., Wealth Destruction on a Massive Scale? A Study of Acquiring-Firm Returns in the Recent Merger Wave, Journal of Finance, Vol. 60, No. 2, p. 757-782, 2005 
Nelson, R., Merger Movements in American Industry, 1895-1956, Princeton University Press/NBER, USA, 1959

Powell, R., Yawson, A., Industry aspects of takeovers and divestitures: Evidence from the UK, Journal of Banking \& Finance, Vol. 29, p. 3015-3040, 2005

Rhodes-Kropf, M., Viswanathan, S., Market valuation and merger waves, Journal of Finance, Vol. 59, No. 6, 2004

Rhodes-Kropf, M., Robinson, D., T., Viswanathan, S., Valuation Waves and Merger Activity: The Empirical Evidence, Journal of Financial Economics, Vol. 77, No. 3, p. 561603, 2005

Shleifer, A., Vishny, R. W., Stock Market Driven Acquisitions, Journal of Financial Economics, Vol. 70, p. 295-311, 2003

Sudarsanam, S., Creating Value from Mergers and Acquisitions, Prentice Hall, Malaysia, 2003

Weston, J. F., The Role of Mergers in the Growth of Large Firms, Berkeley and Los Angeles: University of California Press, 1953

Weston, J. F., Merger and Acquisitions as Adjustment Processes, Journal of Industry, Competition and Trade, Vol. 1, Issue 4, p. 395-410, 2001

Woolridge, J. M., Econometric Analysis of Cross Section and Panel Data, The MIT Press, Cambridge, Massachusetts, 2002. 
Figure 1: Completed merger activity and the average market-to-book ratio 1991-2005

Merger activity is sampled from the Thomson Financial SDC Platinum database, and contains all completed control-shifting transactions, though not newly created joint ventures, mutual fund activity and government mergers. Mergers are maintained regardless of transaction size, and they are allocated to the year of the announcement date. Following the later use of industry median market-to-book values in our empirical investigation, this measure is defined as the yearly average of those values, lagged one period.

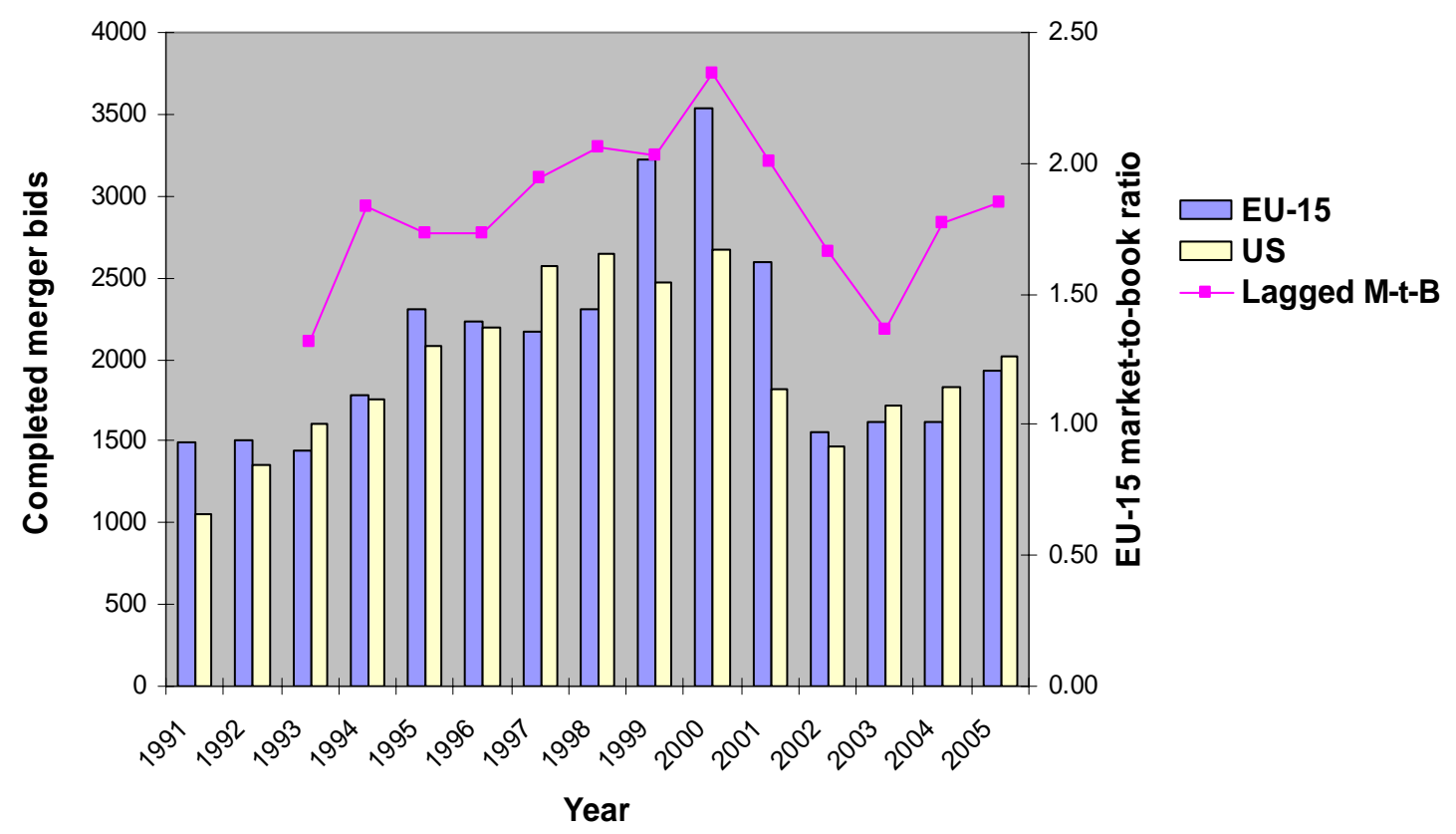


Figure 2: Merger activity, the average market-to-book ratio, and capital liquidity 1991-2005

Merger activity and the market to book ratio are defined as in figure 1 . The rate spread is the yearly average of monthly interest rates on commercial and industrial loans less the central bank rate, calculated as the GDP-

weighted average across EU-15 countries. In this graph, the rate spread has been mirrored at the vertical axis and all values have been raised by the value of the highest observation (2,39\% in 1996). Hence, the 1996 value is zero. Both the market-to-book ratio and the inverted rate spread use the right y-axis, but their axis values indicate percentages for the latter.

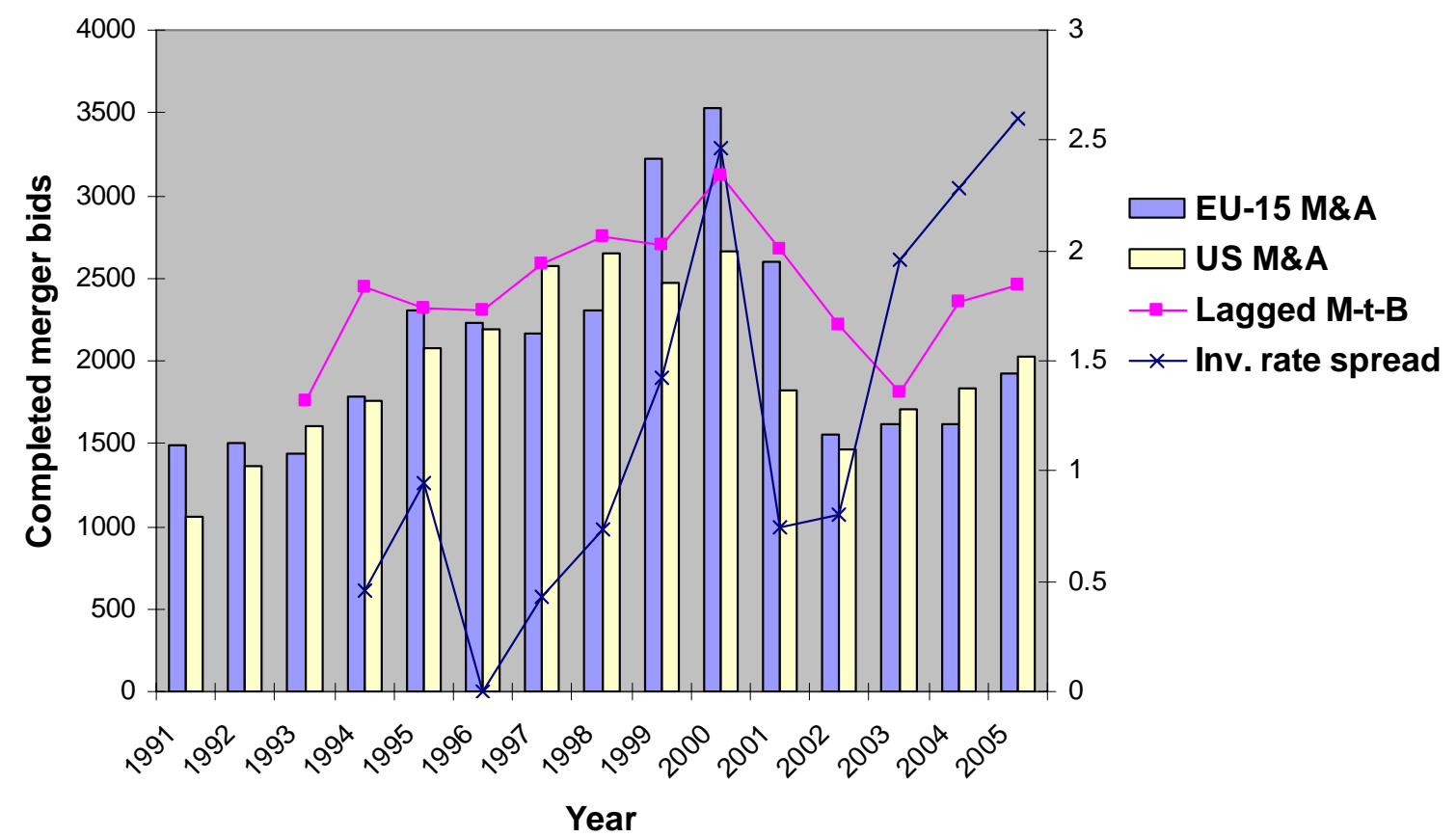


Table 1a: The timing of statistically significant industry merger waves within the EU-15 1995-2004 Industry merger waves and their statistical significance are defined in section 4.2. Significant industry merger waves are depicted for the whole sample and the private firm and public firm sub-samples. The black rectangles signify significant waves in the full sample, while the dark and light greys signify private firm and public firm significant waves respectively. The four columns on the right note the specific starting and ending point of the potential industry merger waves, whether this wave exceeds the $95 \%$ cut-off or not, and lastly, the number of mergers within the entire period.

\begin{tabular}{|c|c|c|c|c|c|c|c|c|c|c|c|c|c|c|c|}
\hline Industry & Sample & 1995 & 1996 & 1997 & 1998 & 1999 & 2000 & 2001 & 2002 & 2003 & 2004 & $\begin{array}{c}\text { Merger } \\
\text { start }\end{array}$ & $\begin{array}{c}\text { Merger } \\
\text { end }\end{array}$ & $\begin{array}{c}95 \% \\
\text { s.s. }\end{array}$ & $\begin{array}{c}\# \\
\text { Mergers }\end{array}$ \\
\hline Aero & $\begin{array}{l}\text { All } \\
\text { Private-private } \\
\text { Public-public }\end{array}$ & & & & & & & & & & & $\begin{array}{l}\text { Jun/95 } \\
\text { Apr/95 } \\
\text { Jun/99 }\end{array}$ & $\begin{array}{l}\text { Jun/97 } \\
\text { Apr/97 } \\
\text { Jun/01 }\end{array}$ & $\begin{array}{l}\mathrm{Y} \\
\mathrm{Y} \\
\mathrm{N}\end{array}$ & $\begin{array}{c}68 \\
4 \\
6\end{array}$ \\
\hline Agric & \begin{tabular}{|l} 
All \\
Private-private \\
Public-public
\end{tabular} & & & & & & & & & & & $\begin{array}{l}\text { Feb/00 } \\
\text { Oct/99 } \\
\text { Jan/03 }\end{array}$ & $\begin{array}{l}\mathrm{Feb} / 02 \\
\mathrm{Oct} / 01 \\
\mathrm{Jan} / 05\end{array}$ & $\begin{array}{l}N \\
Y \\
N\end{array}$ & $\begin{array}{c}102 \\
33 \\
4\end{array}$ \\
\hline Autos & $\begin{array}{l}\text { All } \\
\text { Private-private } \\
\text { Public-public }\end{array}$ & & & & & & & & & & & $\begin{array}{l}\text { Jan/99 } \\
\text { Aug/97 } \\
\text { Apr/97 }\end{array}$ & $\begin{array}{l}\text { Jan/01 } \\
\text { Aug/99 } \\
\text { Apr/99 }\end{array}$ & $\begin{array}{l}\mathrm{Y} \\
\mathrm{N} \\
\mathrm{Y}\end{array}$ & $\begin{array}{l}273 \\
29 \\
34\end{array}$ \\
\hline Bank & \begin{tabular}{|l} 
All \\
Private-private \\
Public-public
\end{tabular} & & & & & & & & & & & $\begin{array}{l}\text { Mar/99 } \\
\text { Mar/99 } \\
\text { Mar/99 }\end{array}$ & $\begin{array}{l}\text { Mar/01 } \\
\text { Mar/01 } \\
\text { Mar/01 }\end{array}$ & $\begin{array}{l} \\
Y \\
Y\end{array}$ & $\begin{array}{l}993 \\
141 \\
169\end{array}$ \\
\hline Beer & \begin{tabular}{|l} 
All \\
Private-private \\
Public-public
\end{tabular} & & & & & & & & & & & $\begin{array}{l}\text { Feb/99 } \\
\text { Jan/01 } \\
\text { Aug/00 }\end{array}$ & $\begin{array}{l}\mathrm{Feb} / 01 \\
\mathrm{Jan} / 03 \\
\text { Aug/02 }\end{array}$ & $\begin{array}{l}\mathrm{N} \\
\mathrm{N} \\
\mathrm{N}\end{array}$ & $\begin{array}{l}231 \\
37 \\
28\end{array}$ \\
\hline BावाMt & \begin{tabular}{|l} 
All \\
Private-private \\
Public-public
\end{tabular} & & & & & & & & & & & $\begin{array}{l}\text { Jun/98 } \\
\text { Oct/99 } \\
\text { Jun/98 }\end{array}$ & $\begin{array}{l}\text { Jun/00 } \\
\text { Oct/01 } \\
\text { Jun/00 }\end{array}$ & $\begin{array}{l}\mathrm{Y} \\
\mathrm{N} \\
\mathrm{Y}\end{array}$ & $\begin{array}{c}689 \\
98 \\
72\end{array}$ \\
\hline Books & \begin{tabular}{|l} 
All \\
Private-private \\
Public-public
\end{tabular} & & & & & & & & & & & $\begin{array}{l}\text { Jul/99 } \\
\text { Jul/96 } \\
\text { Apr/99 }\end{array}$ & $\begin{array}{l}\text { Jul/01 } \\
\text { Jul/98 } \\
\text { Apr/01 }\end{array}$ & $\begin{array}{l} \\
Y \\
Y\end{array}$ & $\begin{array}{l}580 \\
136 \\
24\end{array}$ \\
\hline Boxes & $\begin{array}{l}\text { All } \\
\text { Private-private } \\
\text { Public-public }\end{array}$ & & & & & & & & & & & $\begin{array}{l}\text { May/95 } \\
\text { Nov/96 } \\
\text { Jul/98 }\end{array}$ & $\begin{array}{l}\text { May/97 } \\
\text { Nov/98 } \\
\text { Jul/00 }\end{array}$ & $\begin{array}{l}\mathrm{Y} \\
\mathrm{Y} \\
\mathrm{N}\end{array}$ & $\begin{array}{l}71 \\
14 \\
6\end{array}$ \\
\hline BusSv & $\begin{array}{l}\text { All } \\
\text { Private-private } \\
\text { Public-public }\end{array}$ & & & & & & & & & & & $\begin{array}{l}\text { Jul/99 } \\
\text { Dec/99 } \\
\text { Nov/99 }\end{array}$ & $\begin{array}{l}\text { Jul/01 } \\
\text { Dec/01 } \\
\text { Nov/01 }\end{array}$ & $\begin{array}{l} \\
Y \\
Y\end{array}$ & $\begin{array}{l}3965 \\
676 \\
257\end{array}$ \\
\hline Chems & $\begin{array}{l}\text { All } \\
\text { Private-private } \\
\text { Public-public }\end{array}$ & & & & & & & & & & & $\begin{array}{l}\text { May/97 } \\
\text { Sep/96 } \\
\text { Aug/97 }\end{array}$ & $\begin{array}{l}\text { May/99 } \\
\text { Sep/98 } \\
\text { Aug/99 }\end{array}$ & $\begin{array}{l}\mathrm{Y} \\
\mathrm{N} \\
\mathrm{Y}\end{array}$ & $\begin{array}{l}366 \\
31 \\
37\end{array}$ \\
\hline Chips & \begin{tabular}{|l} 
All \\
Private-private \\
Public-public
\end{tabular} & & & & & & & & & & & $\begin{array}{l}\text { Jun/99 } \\
\text { Mar/00 } \\
\text { Dec/98 }\end{array}$ & $\begin{array}{l}\text { Jun/01 } \\
\text { Mar/02 } \\
\text { Dec/00 }\end{array}$ & $\begin{array}{l}\mathrm{Y} \\
\mathrm{N} \\
\mathrm{Y}\end{array}$ & $\begin{array}{c}441 \\
38 \\
44\end{array}$ \\
\hline Clths & \begin{tabular}{|l} 
All \\
Private-private \\
Public-public
\end{tabular} & & & & & & & & & & & $\begin{array}{l}\text { Nov/99 } \\
\text { Mar/00 } \\
\text { Apr/00 }\end{array}$ & $\begin{array}{l}\text { Nov/01 } \\
\text { Mar/02 } \\
\text { Apr/02 }\end{array}$ & $\begin{array}{l}\mathrm{Y} \\
\mathrm{N} \\
\mathrm{N}\end{array}$ & $\begin{array}{l}113 \\
30 \\
11\end{array}$ \\
\hline Cnstr & \begin{tabular}{|l} 
All \\
Private-private \\
Public-public
\end{tabular} & & & & & & & & & & & $\begin{array}{l}\text { Dec/98 } \\
\text { Mar/95 } \\
\text { Mar/99 }\end{array}$ & $\begin{array}{l}\text { Dec/00 } \\
\text { Mar/97 } \\
\text { Mar/01 }\end{array}$ & $\begin{array}{l}Y \\
Y \\
Y\end{array}$ & $\begin{array}{c}474 \\
59 \\
51\end{array}$ \\
\hline Coal & \begin{tabular}{|l} 
All \\
Private-private \\
Public-public
\end{tabular} & & & & & & & & & & & $\begin{array}{l}\text { Mar/95 } \\
\text { May/95 } \\
\text { Jan/03 }\end{array}$ & $\begin{array}{l}\text { Mar/97 } \\
\text { May/97 } \\
\text { Jan/05 }\end{array}$ & $\begin{array}{l} \\
Y \\
Y\end{array}$ & $\begin{array}{c}27 \\
14 \\
1\end{array}$ \\
\hline Comps & \begin{tabular}{|l} 
All \\
Private-private \\
Public-public
\end{tabular} & & & & & & & & & & & $\begin{array}{l}\text { Jan/99 } \\
\text { Sep/99 } \\
\text { Jun/00 }\end{array}$ & $\begin{array}{l}\text { Jan/01 } \\
\text { Sep/01 } \\
\text { Jun/02 }\end{array}$ & $\begin{array}{l}\mathrm{Y} \\
\mathrm{Y} \\
\mathrm{N}\end{array}$ & $\begin{array}{l}215 \\
20 \\
23\end{array}$ \\
\hline
\end{tabular}


Table 1a: The timing of statistically significant industry merger waves within the EU-15 1995-2004 (continued - page 2)

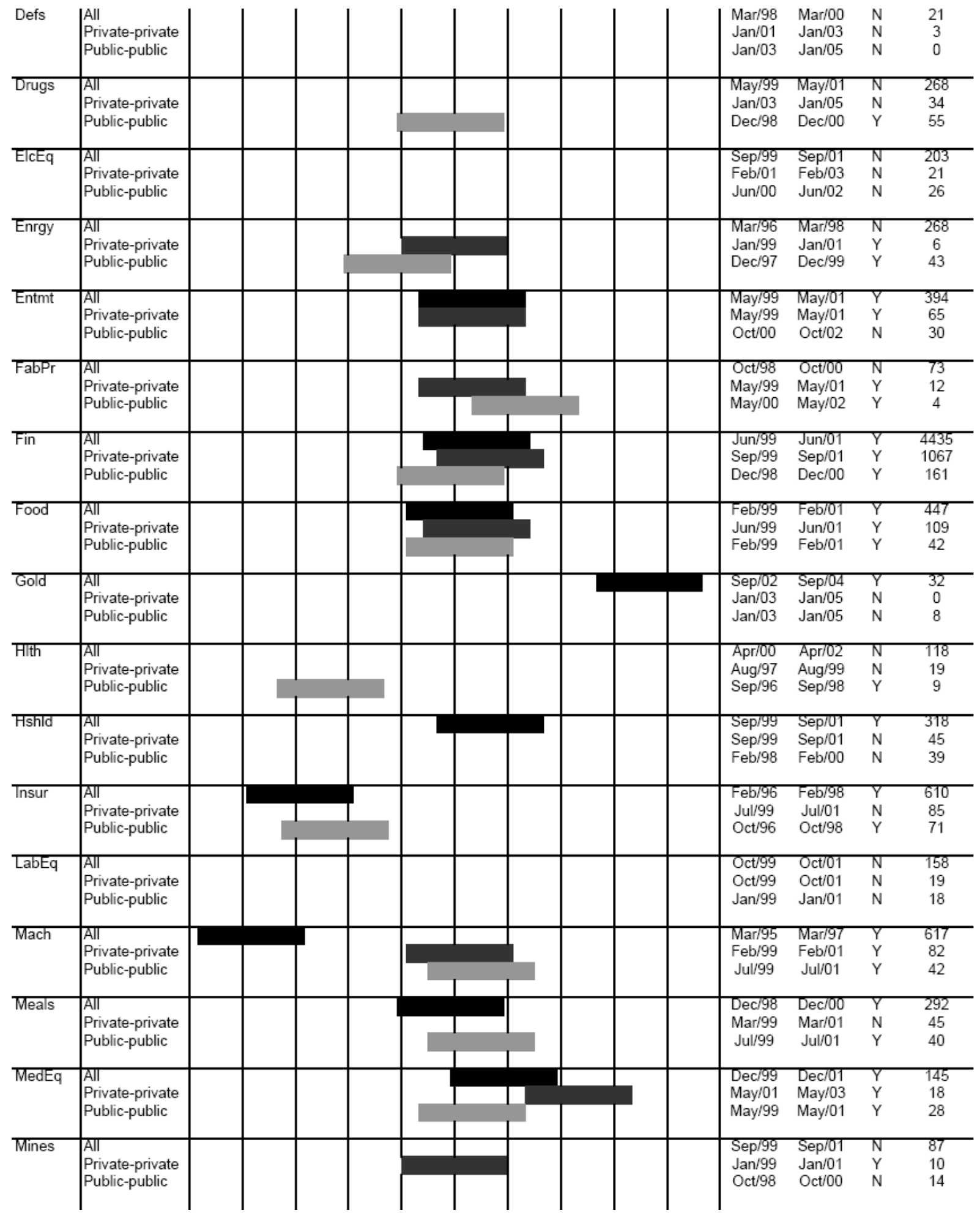


Table 1a: The timing of statistically significant industry merger waves within the EU-15 1995-2004 (continued - page 3 )

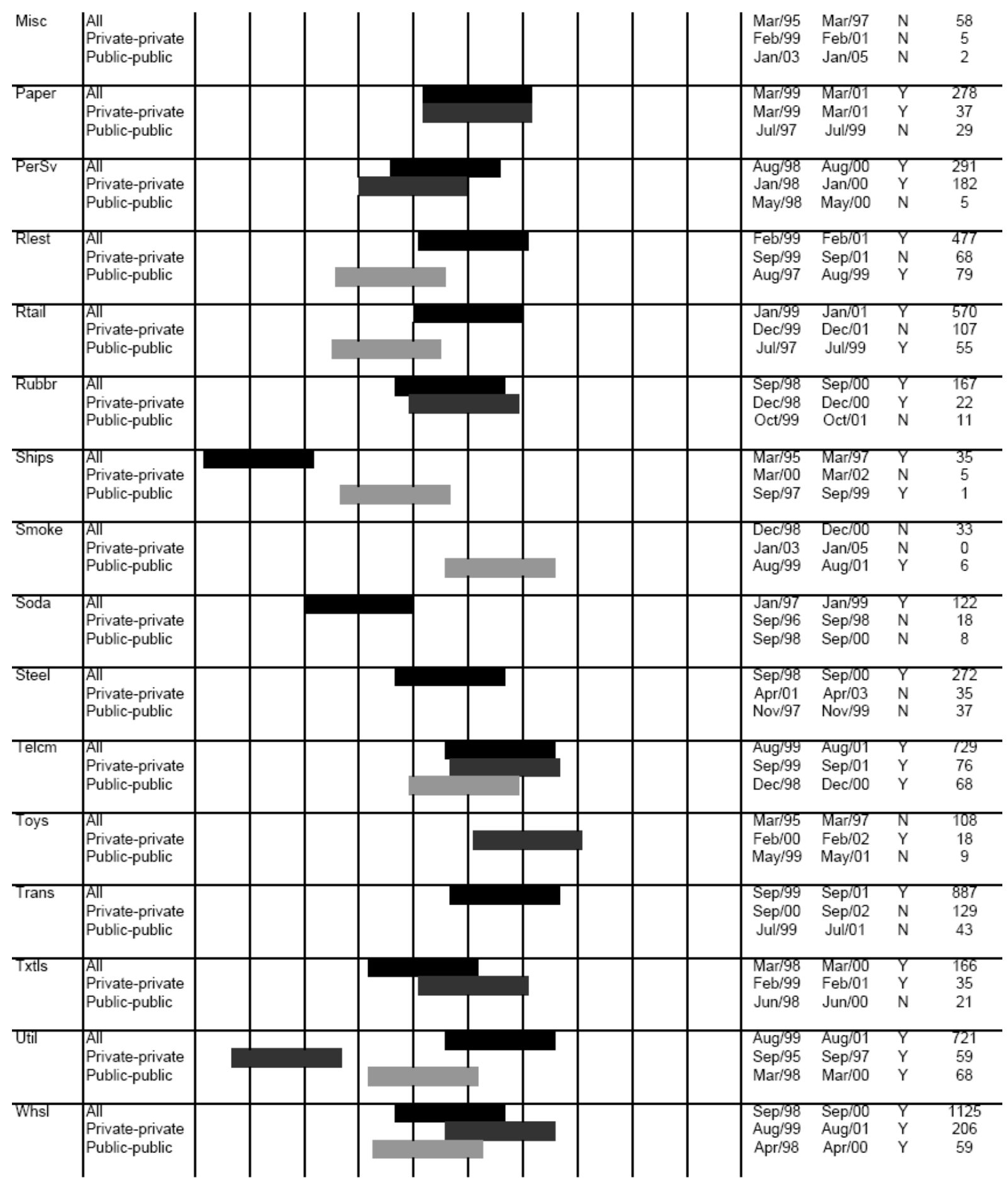


Table 1b: The timing of statistically significant private firm industry merger waves within the EU-15 1995-2004

Industry merger waves and their statistical significance are defined in section 4.2. Significant industry merger waves are depicted for the private firm sub-sample. The black rectangles signify significant waves in the sample, while the light grey rectangles signify non-significant private firm waves. The four columns on the right note the specific starting and ending point of the potential industry merger waves, whether this wave exceeds the $95 \%$ cut-off or not, and lastly, the number of mergers within the entire period.

\begin{tabular}{|c|c|c|c|c|c|c|c|c|c|c|c|c|c|c|c|}
\hline Industry & Sample & 1995 & 1996 & 1997 & 1998 & 1999 & 2000 & 2001 & 2002 & 2003 & 2004 & $\begin{array}{c}\text { Merger } \\
\text { start }\end{array}$ & $\begin{array}{c}\text { Merger } \\
\text { end }\end{array}$ & $\begin{array}{l}95 \% \\
\text { s.s. }\end{array}$ & $\begin{array}{c}\# \\
\text { Mergers }\end{array}$ \\
\hline Aero & Private-private & & & & & & & & & & & Apr/95 & Apr/97 & $\mathrm{Y}$ & 4 \\
\hline Agric & Private-private & & & & & & & & & & & Oct/99 & Oct/01 & $\mathrm{Y}$ & 33 \\
\hline Autos & Private-private & & & & & & & & & & & Aug/97 & Aug/99 & $\mathrm{N}$ & 29 \\
\hline Bank & Private-private & & & & & & & & & & & Mar/99 & Mar/01 & $\mathrm{Y}$ & 141 \\
\hline Beer & Private-private & & & & & & & & & & & Jan/01 & Jan/03 & $\mathrm{N}$ & 37 \\
\hline BldMt & Private-private & & & & & & & & & & & Oct/99 & Oct/01 & $\mathrm{N}$ & 98 \\
\hline Books & Private-private & & & & & & & & & & & Jul/96 & Jul/98 & $\mathrm{Y}$ & 136 \\
\hline Boxes & Private-private & & & & & & & & & & & Nov/96 & Nov/98 & $\mathrm{Y}$ & 14 \\
\hline BusSv & Private-private & & & & & & & & & & & Dec/99 & Dec/01 & $\mathrm{Y}$ & 676 \\
\hline Chems & Private-private & & & & & & & & & & & Sep/96 & Sep/98 & $\mathrm{N}$ & 31 \\
\hline Chips & Private-private & & & & & & & & & & & Mar/00 & Mar/02 & $\mathrm{N}$ & 38 \\
\hline Clths & Private-private & & & & & & & & & & & $\mathrm{Mar} / 00$ & Mar/02 & $\mathrm{N}$ & 30 \\
\hline Cnstr & Private-private & & & & & & & & & & & Mar/95 & Mar/97 & $\mathrm{Y}$ & 59 \\
\hline Coal & Private-private & & & & & & & & & & & May/95 & May/97 & $\mathrm{Y}$ & 14 \\
\hline Comps & Private-private & & & & & & & & & & & Sep/99 & Sep/01 & $Y$ & 20 \\
\hline Defs & Private-private & & & & & & & & & & & Jan/01 & Jan/03 & $\mathrm{N}$ & 3 \\
\hline Drugs & Private-private & & & & & & & & & & & Jan/03 & Jan/05 & $\mathrm{N}$ & 34 \\
\hline ElcEq & Private-private & & & & & & & & & & & Feb/01 & $\mathrm{Feb} / 03$ & $\mathrm{~N}$ & 21 \\
\hline Enrgy & Private-private & & & & & & & & & & & Jan/99 & Jan/01 & $\mathrm{Y}$ & 6 \\
\hline Entmt & Private-private & & & & & & & & & & & May/99 & May/01 & $\mathrm{Y}$ & 65 \\
\hline $\mathrm{FabPr}$ & Private-private & & & & & & & & & & & May/99 & May/01 & Y & 12 \\
\hline Fin & Private-private & & & & & & & & & & & Sep/99 & Sep/01 & $\mathrm{Y}$ & 1067 \\
\hline Food & Private-private & & & & & & & & & & & Jun/99 & Jun/01 & $\mathrm{Y}$ & 109 \\
\hline Gold & Private-private & & & & & & & & & & & Jan/03 & Jan/05 & $\mathrm{N}$ & 0 \\
\hline Hlth & Private-private & & & & & & & & & & & Aug/97 & Aug/99 & $\mathrm{N}$ & 19 \\
\hline Hshld & Private-private & & & & & & & & & & & Sep/99 & Sep/01 & $\mathrm{N}$ & 45 \\
\hline Insur & Private-private & & & & & & & & & & & Jul/99 & Jul/01 & $\mathrm{N}$ & 85 \\
\hline LabEq & Private-private & & & & & & & & & & & Oct/99 & Oct/01 & $\mathrm{N}$ & 19 \\
\hline Mach & Private-private & & & & & & & & & & & Feb/99 & $\mathrm{Feb} / 01$ & Y & 82 \\
\hline Meals & Private-private & & & & & & & & & & & Mar/99 & Mar/01 & $\mathrm{N}$ & 45 \\
\hline MedEq & Private-private & & & & & & & & & & & May/01 & May/03 & $\mathrm{Y}$ & 18 \\
\hline Mines & Private-private & & & & & & & & & & & Jan/99 & Jan/01 & $\mathrm{Y}$ & 10 \\
\hline Misc & Private-private & & & & & & & & & & & Feb/99 & Feb/01 & $\mathrm{N}$ & 5 \\
\hline Paper & Private-private & & & & & & & & & & & $\mathrm{Mar} / 99$ & Mar/01 & $\mathrm{Y}$ & 37 \\
\hline PerSv & Private-private & & & & & & & & & & & Jan/98 & Jan/00 & $Y$ & 182 \\
\hline Rlest & Private-private & & & & & & & & & & & Sep/99 & Sep/01 & $\mathrm{N}$ & 68 \\
\hline Rtail & Private-private & & & & & & & & & & & Dec/99 & $\mathrm{Dec} / 01$ & $\mathrm{~N}$ & 107 \\
\hline Rubbr & Private-private & & & & & & & & & & & Dec/98 & $\mathrm{Dec} / 00$ & $\mathrm{Y}$ & 22 \\
\hline Ships & Private-private & & & & & & & & & & & Mar/00 & Mar/02 & $\mathrm{N}$ & 5 \\
\hline Smoke & Private-private & & & & & & & & & & & Jan/03 & Jan/05 & $\mathrm{N}$ & 0 \\
\hline Soda & Private-private & & & & & & & & & & & Sep/96 & Sep/98 & $\mathrm{N}$ & 18 \\
\hline Steel & Private-private & & & & & & & & & & & Apr/01 & Apr/03 & $\mathrm{N}$ & 35 \\
\hline Telcm & Private-private & & & & & & & & & & & Sep/99 & Sep/01 & $\mathrm{Y}$ & 76 \\
\hline Toys & Private-private & & & & & & & & & & & Feb/00 & $\mathrm{Feb} / 02$ & $\mathrm{Y}$ & 18 \\
\hline Trans & Private-private & & & & & & & & & & & Sep/00 & Sep/02 & $\mathrm{N}$ & 129 \\
\hline Txtls & Private-private & & & & & & & & & & & Feb/99 & $\mathrm{Feb} / 01$ & $\mathrm{Y}$ & 35 \\
\hline Util & Private-private & & & & & & & & & & & Sep/95 & $\mathrm{Sep} / 97$ & $\mathrm{Y}$ & 59 \\
\hline Whsl & Private-private & & & & & & & & & & & Aug/99 & Aug/01 & Y & 206 \\
\hline
\end{tabular}


Table 1c: The timing of statistically significant public firm industry merger waves within the EU-15 1995-2004

Industry merger waves and their statistical significance are defined in section 4.2. Significant industry merger waves are depicted for the public firm sub-sample. The black rectangles signify significant waves in the sample, while the light grey rectangles signify non-significant public firm waves. The four columns on the right note the specific starting and ending point of the potential industry merger waves, whether this wave exceeds the $95 \%$ cut-off or not, and lastly, the number of mergers within the entire period.

\begin{tabular}{|c|c|c|c|c|c|c|c|c|c|c|c|c|c|c|c|}
\hline Industry & & 1995 & 1996 & 1997 & 1998 & 1999 & 2000 & 2001 & 2002 & 2003 & 2004 & $\begin{array}{c}\text { Merger } \\
\text { start }\end{array}$ & $\begin{array}{c}\text { Merger } \\
\text { end }\end{array}$ & $\begin{array}{c}95 \% \\
\text { s.s. }\end{array}$ & $\begin{array}{c}\# \\
\text { Mergers }\end{array}$ \\
\hline $\begin{array}{l}\text { Aero } \\
\text { Agric }\end{array}$ & $\begin{array}{l}\text { Public-public } \\
\text { Public-public }\end{array}$ & & & & & & & & & & & $\begin{array}{l}\text { Jun/99 } \\
\text { Jan/03 }\end{array}$ & $\begin{array}{l}\text { Jun/01 } \\
\text { Jan/05 }\end{array}$ & $\begin{array}{l}\mathrm{N} \\
\mathrm{N}\end{array}$ & $\begin{array}{l}6 \\
4\end{array}$ \\
\hline Autos & Public-public & & & & & & & & & & & Apr/97 & Apr/99 & Y & 34 \\
\hline Bank & Public-public & & & & & & & & & & & Mar/99 & Mar/01 & $Y$ & 169 \\
\hline Beer & Public-public & & & & & & & & & & & Aug/00 & Aug/02 & $\mathrm{N}$ & 28 \\
\hline BldMt & Public-public & & & & & & & & & & & Jun/98 & Jun/00 & $Y$ & 72 \\
\hline Books & Public-public & & & & & & & & & & & Apr/99 & Apr/01 & $Y$ & 24 \\
\hline Boxes & Public-public & & & & & & & & & & & Jul/98 & Jul/00 & $\mathrm{N}$ & 6 \\
\hline BusSv & Public-public & & & & & & & & & & & Nov/99 & Nov/01 & $Y$ & 257 \\
\hline Chems & Public-public & & & & & & & & & & & Aug/97 & Aug/99 & $\mathrm{Y}$ & 37 \\
\hline Chips & Public-public & & & & & & & & & & & Dec/98 & $\mathrm{Dec} / 00$ & Y & 44 \\
\hline Clths & Public-public & & & & & & & & & & & Apr/00 & Apr/02 & $\mathrm{N}$ & 11 \\
\hline Cnstr & Public-public & & & & & & & & & & & Mar/99 & Mar/01 & Y & 51 \\
\hline Coal & Public-public & & & & & & & & & & & Jan/03 & Jan/05 & $Y$ & 1 \\
\hline Comps & Public-public & & & & & & & & & & & Jun/00 & Jun/02 & $\mathrm{N}$ & 23 \\
\hline Defs & Public-public & & & & & & & & & & & Jan/03 & Jan/05 & $\mathrm{N}$ & 0 \\
\hline Drugs & Public-public & & & & & & & & & & & Dec/98 & $\mathrm{Dec} / 00$ & $Y$ & 55 \\
\hline ElcĔq & Public-public & & & & & & & & & & & Jun/00 & Jun/02 & $\mathrm{N}$ & 26 \\
\hline Enrgy & Public-public & & & & & & & & & & & $\operatorname{Dec} / 97$ & Dec/99 & $Y$ & 43 \\
\hline Entmt & Public-public & & & & & & & & & & & Oct $/ 00$ & Oct/02 & $\mathrm{N}$ & 30 \\
\hline $\mathrm{FabPr}$ & Public-public & & & & & & & & & & & May/00 & May/02 & $\mathrm{Y}$ & 4 \\
\hline Fin & Public-public & & & & & & & & & & & Dec/98 & $\mathrm{Dec} / 00$ & $\mathrm{Y}$ & 161 \\
\hline Food & Public-public & & & & & & & & & & & Feb/99 & Feb/01 & $\mathrm{Y}$ & 42 \\
\hline Gold & Public-public & & & & & & & & & & & Jan/03 & Jan/05 & $\mathrm{N}$ & 8 \\
\hline Hlth & Public-public & & & & & & & & & & & Sep/96 & Sep/98 & $\mathrm{Y}$ & 9 \\
\hline Hshld & Public-public & & & & & & & & & & & Feb/98 & Feb/00 & $\mathrm{N}$ & 39 \\
\hline Insur & Public-public & & & & & & & & & & & Oct/96 & Oct/98 & $\mathrm{Y}$ & 71 \\
\hline LabEq & Public-public & & & & & & & & & & & Jan/99 & Jan/01 & $\mathrm{N}$ & 18 \\
\hline Mach & Public-public & & & & & & & & & & & May/98 & May/00 & $\mathrm{Y}$ & 42 \\
\hline Meals & Public-public & & & & & & & & & & & Jul/99 & Jul/01 & $Y$ & 40 \\
\hline MedEq & Public-public & & & & & & & & & & & May/99 & May/01 & $\mathrm{Y}$ & 28 \\
\hline Mines & Public-public & & & & & & & & & & & Oct/98 & Oct/00 & $\mathrm{N}$ & 14 \\
\hline Misc & Public-public & & & & & & & & & & & Jan/03 & Jan/05 & $\mathrm{N}$ & 2 \\
\hline Paper & Public-public & & & & & & & & & & & Jul/97 & Jul/99 & $\mathrm{N}$ & 29 \\
\hline PerSv & Public-public & & & & & & & & & & & May/98 & May/00 & $\mathrm{N}$ & 5 \\
\hline Rlest & Public-public & & & & & & & & & & & Aug/97 & Aug/99 & Y & 79 \\
\hline Rtail & Public-public & & & & & & & & & & & $\mathrm{Jul} / 97$ & Jul/99 & $Y$ & 55 \\
\hline Rubbr & Public-public & & & & & & & & & & & Oct/99 & Oct/01 & $\mathrm{N}$ & 11 \\
\hline Ships & Public-public & & & & & & & & & & & Sep/97 & Sep/99 & Y & 1 \\
\hline Smoke & Public-public & & & & & & & & & & & Aug/99 & Aug/01 & $Y$ & 6 \\
\hline Soda & Public-public & & & & & & & & & & & Sep/98 & Sep/00 & $\mathrm{N}$ & 8 \\
\hline Steel & Public-public & & & & & & & & & & & Nov/97 & Nov/99 & $\mathrm{N}$ & 37 \\
\hline Telcm & Public-public & & & & & & & & & & & $\operatorname{Dec} / 98$ & $\mathrm{Dec} / 00$ & $Y$ & 68 \\
\hline Toys & Public-public & & & & & & & & & & & May/99 & May/01 & $\mathrm{N}$ & 9 \\
\hline Trans & Public-public & & & & & & & & & & & $\mathrm{Jul} / 99$ & Jul/01 & $\mathrm{N}$ & 43 \\
\hline Txtls & Public-public & & & & & & & & & & & Jun/98 & Jun/00 & $\mathrm{N}$ & 21 \\
\hline Util & Public-public & & & & & & & & & & & Mar/98 & Mar/00 & $Y$ & 68 \\
\hline Whsl & Public-public & & & & & & & & & & & Apr/98 & Apr/00 & $\mathrm{Y}$ & 59 \\
\hline
\end{tabular}


Table 2: Mean rank values of the predictive variables preceding significant industry merger waves within the EU-15 1995-2004

Mean rank values (with significance in brackets) are reported for the whole sample and the sub-samples. The 4 samples are: all mergers; mergers of privately held acquirers and targets; mergers of private acquirers and public targets; mergers of public acquirers and private targets; mergers of public acquirers and targets. Ranks are based on quartiles constructed using the sample times series of each variable. Significance is based on the t-test of the null hypothesis that mean rank equals 2,5 .

\begin{tabular}{|c|c|c|c|c|c|c|}
\hline Variables & Definition & $\begin{array}{l}\text { Mean rank: } \\
\text { All mergers }\end{array}$ & $\begin{array}{c}\text { Mean rank: } \\
\text { Private mergers }\end{array}$ & $\begin{array}{l}\text { Mean rank: } \\
\text { Private-public } \\
\text { mergers }\end{array}$ & $\begin{array}{l}\text { Mean rank: } \\
\text { Public-private } \\
\text { mergers }\end{array}$ & $\begin{array}{c}\text { Mean rank: } \\
\text { Public mergers }\end{array}$ \\
\hline Economic shock & (All median absolute changes) & & & & & \\
\hline Capital liquidity & $\begin{array}{l}\text { Average rate on commercial and industrial } \\
\text { loans }_{\mathrm{t}} \text { - the central bank rate } \\
\mathrm{t}\end{array}$ & $\begin{array}{c}2,71 \\
(0,239)\end{array}$ & $\begin{array}{c}2,35 \\
(0,390)\end{array}$ & $\begin{array}{l}2,06^{* *} \\
(0,027)\end{array}$ & $\begin{array}{c}2,48 \\
(0,922)\end{array}$ & $\begin{array}{l}3,26^{* * *} \\
(0,002)\end{array}$ \\
\hline Cash flow margin & Operational profit $_{t} /$ Sales $_{t}$ & $\begin{array}{l}3,39^{* * *} \\
(<0,001)\end{array}$ & $\begin{array}{l}3,39^{* * *} \\
(<0,001)\end{array}$ & $\begin{array}{l}3,06^{* *} \\
(0,030)\end{array}$ & $\begin{array}{l}3,52^{* * *} \\
(<0,001)\end{array}$ & $\begin{array}{c}2,96^{*} \\
(0,052)\end{array}$ \\
\hline Asset turnover & Sales $_{t} /$ Total $_{\text {assets }}$ t-1 & $\begin{array}{l}3,19^{* * *} \\
(<0,001)\end{array}$ & $\begin{array}{l}3,08^{* * *} \\
(0,003)\end{array}$ & $\begin{array}{c}2,76 \\
(0,208)\end{array}$ & $\begin{array}{l}3,36^{* * *} \\
(<0,001)\end{array}$ & $\begin{array}{l}2,91^{* *} \\
(0,049)\end{array}$ \\
\hline Return on assets & Operational profit $/$ / Total assets $_{t}$ & $\begin{array}{l}3,26^{* * *} \\
(<0,001)\end{array}$ & $\begin{array}{l}3,17^{* * *} \\
(<0,001)\end{array}$ & $\begin{array}{c}2,88 \\
(0,154)\end{array}$ & $\begin{array}{l}3,32^{* * *} \\
(<0,001)\end{array}$ & $\begin{array}{l}2,91^{* *} \\
(0,049)\end{array}$ \\
\hline Employee growth & $\begin{array}{c}\left(\text { No. of employees }_{t}-\text { No. of employees }\right. \\
\text { No. }) / \\
\text { No. of employees } \\
t-1\end{array}$ & $\begin{array}{l}3,00^{* * *} \\
(0,002)\end{array}$ & $\begin{array}{l}3,00^{* * *} \\
(0,007)\end{array}$ & $\begin{array}{c}3,00^{*} \\
(0,070)\end{array}$ & $\begin{array}{l}2,96^{* *} \\
(0,027)\end{array}$ & $\begin{array}{c}2,48 \\
(0,929)\end{array}$ \\
\hline Sales growth & $\left(\right.$ Sales $_{t}-$ Sales $\left._{t-1}\right) /$ Sales $_{t-1}$ & $\begin{array}{l}3,42^{* * *} \\
(<0,001)\end{array}$ & $\begin{array}{l}3,22^{* * *} \\
(<0,001)\end{array}$ & $\begin{array}{l}2,94^{* *} \\
(0,043)\end{array}$ & $\begin{array}{l}3,48^{* * *} \\
(<0,001)\end{array}$ & $\begin{array}{c}2,83 \\
(0,159)\end{array}$ \\
\hline Cap. expenditures & Capital expenditures $_{t} /$ Total $_{\text {assets }} \mathrm{t}_{\mathrm{t}-1}$ & $\begin{array}{l}3,26^{* * *} \\
(<0,001)\end{array}$ & $\begin{array}{l}3,31^{* * *} \\
(<0,001)\end{array}$ & $\begin{array}{l}3,53^{* * *} \\
(<0,001)\end{array}$ & $\begin{array}{l}3,400^{* * *} \\
(<0,001)\end{array}$ & $\begin{array}{c}2,70 \\
(0,322)\end{array}$ \\
\hline Economic shock index & $\begin{array}{l}\text { First principal component of Cash flow } \\
\text { margin, ROA, Employee growth, Asset } \\
\text { turnover, Sales growth. Cap. expenditures }\end{array}$ & $\begin{array}{l}3,32^{* * *} \\
(<0,001)\end{array}$ & $\begin{array}{l}3,17^{* * *} \\
(<0,001)\end{array}$ & $\begin{array}{c}2,88^{*} \\
(0,085)\end{array}$ & $\begin{array}{l}3,44^{* * *} \\
(<0,001)\end{array}$ & $\begin{array}{c}2,78 \\
(0,225)\end{array}$ \\
\hline
\end{tabular}


Table 2 - continued - page 2

\begin{tabular}{|c|c|c|c|c|c|c|}
\hline Variables & Definition & $\begin{array}{l}\text { Mean rank: } \\
\text { All mergers }\end{array}$ & $\begin{array}{c}\text { Mean rank: } \\
\text { Private mergers }\end{array}$ & $\begin{array}{c}\text { Mean rank: } \\
\text { Private-public } \\
\text { mergers }\end{array}$ & $\begin{array}{c}\text { Mean rank: } \\
\text { Public-private } \\
\text { mergers }\end{array}$ & $\begin{array}{l}\text { Mean rank: } \\
\text { Public mergers }\end{array}$ \\
\hline \multicolumn{7}{|l|}{$\begin{array}{l}\text { Market driven / agency } \\
\text { costs }\end{array}$} \\
\hline Market to book & $\begin{array}{l}\text { Market capitalization }{ }_{\mathrm{t}-1} \text { to Shareholder } \\
\text { Equity } \mathrm{t}_{-1}\end{array}$ & $\begin{array}{c}3,23^{* * *} \\
(<0,001)\end{array}$ & $\begin{array}{c}2,61 \\
(0,646)\end{array}$ & $\begin{array}{c}2,35 \\
(0,594)\end{array}$ & $\begin{array}{c}3,28^{* * *} \\
(<0,001)\end{array}$ & $\begin{array}{c}3,22^{* * *} \\
(<0,001)\end{array}$ \\
\hline $\begin{array}{l}\text { Dispersion in market to } \\
\text { book }\end{array}$ & $\begin{array}{c}\text { Intra-industry dispersion in market-to-book } \\
\text { values }\end{array}$ & $\begin{array}{c}2,58 \\
(0,665)\end{array}$ & $\begin{array}{c}2,52 \\
(0,924)\end{array}$ & $\begin{array}{c}2,88 \\
(0,132)\end{array}$ & $\begin{array}{c}2,76 \\
(0,261)\end{array}$ & $\begin{array}{c}2,78 \\
(0,207)\end{array}$ \\
\hline 1 year returns & Median industry 1- year cumulative returns & $\begin{array}{c}2,71 \\
(0,284)\end{array}$ & $\begin{array}{c}2,35 \\
(0,519)\end{array}$ & $\begin{array}{c}2,24 \\
(0,332)\end{array}$ & $\begin{array}{c}2,84^{*} \\
(0,071)\end{array}$ & $\begin{array}{l}3,09^{* * *} \\
(0,007)\end{array}$ \\
\hline 3 year returns & Median industry 3-year cumulative returns & $\begin{array}{l}3,13^{* * *} \\
(<0,001)\end{array}$ & $\begin{array}{c}2,78 \\
(0,188)\end{array}$ & $\begin{array}{l}3,06^{* *} \\
(0,030)\end{array}$ & $\begin{array}{l}3,32^{* * *} \\
(<0,001)\end{array}$ & $\begin{array}{c}2,87^{*} \\
(0,054)\end{array}$ \\
\hline $\begin{array}{l}\text { Dispersion in } 1 \text { year } \\
\text { returns }\end{array}$ & $\begin{array}{l}\text { Intra-industry dispersion of the 1-year } \\
\text { cumulative returns }\end{array}$ & $\begin{array}{c}2,81 \\
(0,103)\end{array}$ & $\begin{array}{c}2,96^{*} \\
(0,061)\end{array}$ & $\begin{array}{c}2,76 \\
(0,277)\end{array}$ & $\begin{array}{c}2,68 \\
(0,439)\end{array}$ & $\begin{array}{c}2,22^{*} \\
(0,079)\end{array}$ \\
\hline $\begin{array}{l}\text { Dispersion in } 3 \text { year } \\
\text { returns }\end{array}$ & $\begin{array}{l}\text { Intra-industry dispersion of the 3-year } \\
\text { cumulative returns }\end{array}$ & $\begin{array}{c}2,97^{* *} \\
(0,013)\end{array}$ & $\begin{array}{l}3,26^{* * *} \\
(0,002)\end{array}$ & $\begin{array}{c}3,00^{*} \\
(0,098)\end{array}$ & $\begin{array}{l}3,00^{* *} \\
(0,024)\end{array}$ & $\begin{array}{c}2,78 \\
(0,225)\end{array}$ \\
\hline $\begin{array}{l}\text { Industry time series } \\
\text { error }\end{array}$ & $\begin{array}{c}\text { Version } 2 \text { of the time series error in Rhodes- } \\
\text { Kropf et al } 2005\end{array}$ & $\begin{array}{c}2,71 \\
(0,187)\end{array}$ & $\begin{array}{c}2,65 \\
(0,503)\end{array}$ & $\begin{array}{c}2,41 \\
(0,681)\end{array}$ & $\begin{array}{c}2,88^{*} \\
(0,052)\end{array}$ & $\begin{array}{c}2,74 \\
(0,247)\end{array}$ \\
\hline
\end{tabular}


Table 3: Logistic regression modelling of significant industry merger waves within the EU-15 1995-2004 This table shows a pooled logistic regression modelling of the occurrence of an industry merger wave. The 4 samples are: all mergers; mergers of privately held acquirers and targets; mergers of private acquirers and public targets; mergers of public acquirers and private targets; mergers of public acquirers and targets. The dependent variable is industry years. It is coded ' 1 ' if a statistically significant industry merger wave begins. If not, it is coded ' 0 '. Each sample counts 420 industry years. The explanatory variables are the market driven variables (1-year and 3-year stock returns, and the industry dispersion in these stock returns), the economic shock variables (economic shock index, capital liquidity and tight capital interacted with the shock index), as well two neutral variables (market to book and its industry dispersion). 'Capital liquidity' is the aggregated spread between the commercial bank lending rate and the central bank marginal lending rate. 'Tight capital' is ' 1 ' when Capital liquidity is below its time series median. The economic shock index is the first principal component of Cash flow margin, Asset turnover, Employee growth, ROA, and Sales growth. All variables are evaluated at the preceding year end, except Capital liquidity, which is evaluated in the given year. The marginal effects of the explanatory variables - evaluated at their sample mean - are reported (the intercept has no marginal effect), along with their significance (of a $\chi^{2}$-test) in parenthesis. *, ** and *** marks significance at the $10 \%, 5 \%$ and $1 \%$ level respectively.

\begin{tabular}{|c|c|c|c|c|c|}
\hline Variable & All mergers & $\begin{array}{l}\text { Private } \\
\text { mergers }\end{array}$ & $\begin{array}{c}\text { Private- } \\
\text { public } \\
\text { mergers }\end{array}$ & $\begin{array}{l}\text { Public- } \\
\text { private } \\
\text { mergers }\end{array}$ & $\begin{array}{c}\text { Public } \\
\text { mergers }\end{array}$ \\
\hline 1 year stock return ${ }_{t-1}$ & $\begin{array}{c}0,073 \\
(0,490)\end{array}$ & $\begin{array}{l}-0,088 \\
(0,258)\end{array}$ & $\begin{array}{l}-0,059^{*} \\
(0,052)\end{array}$ & $\begin{array}{c}0,031 \\
(0,788)\end{array}$ & $\begin{array}{l}0,106^{* *} \\
(0,029)\end{array}$ \\
\hline $\begin{array}{l}\text { Dispersion in } 1 \text { year stock } \\
\text { return }_{t-1}\end{array}$ & $\begin{array}{l}-0,044 \\
(0,270)\end{array}$ & $\begin{array}{c}0,003 \\
(0,819)\end{array}$ & $\begin{array}{c}0,001 \\
(0,828)\end{array}$ & $\begin{array}{c}0,011 \\
(0,368)\end{array}$ & $\begin{array}{l}-0,079^{* * *} \\
(<0,001)\end{array}$ \\
\hline 3 year stock return $n_{t-1}$ & $\begin{array}{c}0,053 \\
(0,362)\end{array}$ & $\begin{array}{c}0,058 \\
(0,194)\end{array}$ & $\begin{array}{l}0,061^{* *} \\
(0,016)\end{array}$ & $\begin{array}{c}0,016 \\
(0,793)\end{array}$ & $\begin{array}{c}0,011 \\
(0,603)\end{array}$ \\
\hline $\begin{array}{l}\text { Dispersion in } 3 \text { year stock } \\
\text { return }_{t-1}\end{array}$ & $\begin{array}{l}-0,001 \\
(0,965)\end{array}$ & $\begin{array}{c}0,001 \\
(0,932)\end{array}$ & $\begin{array}{l}-0,003 \\
(0,420)\end{array}$ & $\begin{array}{c}0,006 \\
(0,295)\end{array}$ & $\begin{array}{c}0,000 \\
(0,947)\end{array}$ \\
\hline Market to book b $_{t-1}$ & $\begin{array}{l}-0,014 \\
(0,613)\end{array}$ & $\begin{array}{l}-0,015 \\
(0,509)\end{array}$ & $\begin{array}{l}-0,020^{*} \\
(0,078)\end{array}$ & $\begin{array}{l}-0,012 \\
(0,689)\end{array}$ & $\begin{array}{l}-0,005 \\
(0,614)\end{array}$ \\
\hline $\begin{array}{l}\text { Dispersion in market to } \\
\text { book }_{t-1}\end{array}$ & $\begin{array}{c}0,026 \\
(0,367)\end{array}$ & $\begin{array}{c}0,020 \\
(0,379)\end{array}$ & $\begin{array}{l}-0,007 \\
(0,514)\end{array}$ & $\begin{array}{c}0,012 \\
(0,691)\end{array}$ & $\begin{array}{c}0,016 \\
(0,124)\end{array}$ \\
\hline Economic shock index $_{t-1}$ & $\begin{array}{l}0,428^{* *} \\
(0,021)\end{array}$ & $\begin{array}{l}0,310^{*} \\
(0,051)\end{array}$ & $\begin{array}{l}0,113^{*} \\
(0,059)\end{array}$ & $\begin{array}{c}0,546 \\
(0,129)\end{array}$ & $\begin{array}{l}-0,038 \\
(0,579)\end{array}$ \\
\hline $\begin{array}{l}\left(\text { Economic shock index }_{t-1}\right) * \\
\left(\text { Tight capital }_{t}\right)\end{array}$ & $\begin{array}{c}0,294 \\
(0,840)\end{array}$ & $\begin{array}{c}0,535 \\
(0,116)\end{array}$ & $\begin{array}{c}0,154 \\
(0,521)\end{array}$ & $\begin{array}{l}-0,109 \\
(0,975)\end{array}$ & $\begin{array}{l}-0,049 \\
(0,770)\end{array}$ \\
\hline Capital liquidity & $\begin{array}{l}-0,002 \\
(0,923)\end{array}$ & $\begin{array}{l}-0,000 \\
(0,991)\end{array}$ & $\begin{array}{l}-0,016^{* *} \\
(0,025)\end{array}$ & $\begin{array}{c}0,015 \\
(0,489)\end{array}$ & $\begin{array}{c}0,04 \\
(0,653)\end{array}$ \\
\hline
\end{tabular}

